\title{
Surgical outcomes of laparoscopic radical hysterectomy for patients with early cervical cancer: Initial experience in Cancer Institute
}

\author{
Resultados quirúrgicos de histerectomía radical laparoscópica en pacientes con cáncer \\ de cérvix en etapa temprana: experiencia inicial en Instituto de Cáncer
}

\section{David Isla-Ortiz" ${ }^{*}$, Rosa A. Salcedo-Hernández', Alberto M. León-Takahashi', Fabiola Estrada-Rivera³, Salim A. Barquet-Muñoz ${ }^{1}$ and Nancy Reynoso-Noverón ${ }^{2}$}

${ }^{1}$ Department of Gynecologic Oncology; ${ }^{2}$ Epidemilogy Department. Instituto Nacional de Cancerología México; ${ }^{3}$ Department of Gynecologic Oncology, Instituto Nacional de Perinatología México. Mexico City, Mexico

\begin{abstract}
Background: Open radical hysterectomy with bilateral pelvic lymphadenectomy is the standard treatment in early stages (1A2-1B1) of uterine cervical cancer (UCC); laparoscopic radical hysterectomy ( $L R H)$ is a safe and viable option. Objective: To evaluate the safety and feasibility of $L R H$ in a hospital cancer care center. Method: Retrospective study that included the first 17 patients with UCC in an early stage operated with LRH in the period from April 2013 to November 2016 at the National Cancer Institute of Mexico. Results: The 17 patients were stage IB1 clinical, of which 10 (58.8\%) was epidermoid subtype, $4(23.5 \%)$ adenocarcinoma and $3(17.6 \%)$ adenoescamoso. The mean age was $42 \pm 8$ years. The tumor size was $2.3 \pm 0.9 \mathrm{~cm}$, and in $94.1 \%$ the surgical margins were free of disease. The average operative time was $341 \pm 65$ minutes and blood loss of $107 \pm 64 \mathrm{ml}$, no patient required blood transfusion and there was no case of conversion to open surgery. The average length of hospital stay was 2.7 days (range: 2-7 days). There were no intraoperative or postoperative complications. Conclusions: $L R H$ is a safe and reliable alternative for the treatment of early stage UCC.
\end{abstract}

KEY WORDS: Radical hysterectomy. Early stage. Cervical cancer.

\section{Resumen}

Antecedentes: La histerectomía radical abierta con linfadenectomía pélvica bilateral es el tratamiento estándar para el cáncer de cérvix uterino (CACU) en etapas temprana (1A2-1B1); la histerectomía radical por laparoscopia (HRL) es una opción segura y viable. Objetivo: Evaluar la seguridad y la factibilidad de la HRL en un centro hospitalario de atención de cáncer. Método: Estudio retrospectivo que incluyó 17 pacientes con CACU en etapa temprana intervenidas con HRL entre abril de 2013 y noviembre de 2016 en el Instituto Nacional de Cancerología de México. Resultados: Las 17 pacientes se encontraban en etapa clínica IB1, en 10 (58.8\%) fue subtipo epidermoide, en 4 (23.5\%) adenocarcinoma y en 3 (17.6\%) adenoescamoso. La media de edad fue de $42 \pm 8$ años. El tamaño del tumor fue de $2.3 \pm 0.9 \mathrm{~cm}$, y en el $94.1 \%$ los márgenes quirúrgicos estaban libres de enfermedad. El promedio de tiempo operatorio fue de $341 \pm 65$ minutos, con una pérdida sanguínea de 107 $\pm 64 \mathrm{ml}$, no requirieron trasfusión sanguínea y no hubo conversión a cirugía abierta. La media de estancia hospitalaria fue de

\author{
Correspondence: \\ *David Isla-Ortiz \\ Av. San Fernando, 22 \\ Col. Sección XVI, Del. Tlalpan \\ C.P. 14080 , Ciudad de México, México \\ E-mail: islasurgery@ hotmail.com
}

Date of reception: 08-02-2018

Date of acceptance: 02-04-2018

DOI: 10.24875/CIRUE.M18000034
Cir Cir. 2018;86:193-200

Contents available at PubMed www.cirugiaycirujanos.com 
2.7 días (rango: 2-7 días). No se presentaron complicaciones intraoperatorias ni posoperatorias. Conclusiones: La HRL es una alternativa segura y confiable para el tratamiento del CACU en etapa temprana.

PALABRAS CLAVE: Histerectomía radical laparoscópica. Etapa temprana. Cáncer de cérvix.

\section{Introduction}

Cervical cancer is the second most common cancer in women in developing countries and the seventh most common in developed countries ${ }^{1,2}$. In Mexico, a developing country, it remains a public health problem, since in addition to being the second cancer in terms of incidence and mortality, it continues to be detected at locally advanced stages ${ }^{3}$. However, with efficacious use of cervical cancer early detection, many women will be diagnosed at childbearing age $(\mathrm{IA} 2 \text { and IB1 })^{4}$, with standard treatment being open radical hysterectomy with bilateral pelvic lymphadenectomy ${ }^{5}$. The laparoscopic approach described by Canis et al. ${ }^{6}$ and Nezhat et al. ${ }^{7}$ has been shown to be safe and feasible in multiple studies, with oncological results similar to those observed with the open route, but with a lower rate of surgical morbidity, less bleeding, shorter hospital stay and earlier reincorporation to daily activities. Steed et al. ${ }^{8}$ compared, from 1996 to 2003, perioperative morbidity in 71 patients treated with laparoscopic radical hysterectomy $(\mathrm{LRH})$ in comparison with 205 patients treated with open radical hysterectomy, with blood losses of 300 and $500 \mathrm{~mL}$, and a surgical time of 3.5 and 2.5 hours, respectively, being reported. Laparoscopy intraoperative complications included cystotomy, ureteral injury and intestinal injury; therefore, it is concluded that $\mathrm{LRH}$ is a safe procedure, with low general morbidity and low complication rates ${ }^{8}$. LRH is practiced in developed countries and in some developing countries. One of the concerns regarding prospective and multicenter studies on gynecological surgery, particularly in those involving the use of laparoscopic surgery, is the type and quality of technology available in developing countries, which would limit the use of this approach, but comparing a series of cases on the implementation of this approach with the experiences of developed countries will allow assessing the feasibility and safety of LRH with bilateral pelvic lymphadenectomy. Therefore, the purpose of this study is to show the initial experience on the implementation of this type surgery in the National Institute of Cancerology of Mexico for the treatment of cervical cancer at early stages, as well as to compare the pathological and surgical outcomes and complications with those reported in the literature.

\section{Method}

A retrospective review of all patients diagnosed with early-stage cervical cancer (IA2-IB1, according to the International Federation of Gynecology and Obstetrics [FIGO]) who underwent LRH within the period from April 2013 to November 2016 at the National Cancerology Institute of Mexico was carried out. Patients with squamous cell, adenocarcinoma or adenosquamous histologies were included, with other histological types being excluded.

The following data were collected: age, clinical stage, histology, surgical time, bleeding, blood transfusion, transoperative and postoperative complications, conversion to open surgery, days of hospital stay and morbidity during the first 30 postoperative days. Evaluation of the radicalness of the procedure was also obtained, which was defined as the identification of all anatomical structures and the place of section at the level of the limits described by Querleu and Morrow ${ }^{9}$, and pathology findings reports, such as tumor size, infiltration to cervical stroma, lymphovascular permeation, number of lymph nodes, evaluation of the parametria and resection surgical margins.

\section{Surgical technique}

The surgical technique used is the following: under general anesthesia, patients are placed in the Trendelenburg position and the procedure is started with the placement of a uterine manipulator such as VCare ${ }^{\circledR}$ Uterine Manipulator/Elevator (ConMed Endosurgery, Utica, NY) in the uterus. Subsequently, through a 10$\mathrm{mm}$ supraumbilical incision, an Endopath Bladeless Trocarendopath Optiview Optical Obturator (Ethicon) trocar is introduced into the abdominal cavity and insufflated with $\mathrm{CO}_{2}$ to a pressure of $15 \mathrm{mmHg}$. Four 5-mm trocars are used; two are placed right and left of the lower quadrants, and the other two on the right and left of the flanks at the level of the umbilical scar. The abdominal cavity is then explored, with the opening performed with a monopolar incision of the broad 
ligament in a triangle formed by the round ligament, the psoas muscle and the infundibulopelvic ligament, with the incision following a parallel direction to the latter; this it is achieved by placing the uterus in counter-traction to the incision and the round ligament being pulled cephalad, with the retroperitoneal paravesical and pararectal spaces, and subsequently the recto-vaginal space being dissected, as well as the vesico-vaginal tissue. The round ligaments and the infundibulopelvic ligament are then sectioned (except for cases where the ovaries are preserved). Pelvic lymph nodes are explored to rule out evidence of malignancy to then proceed to identify the uterine arteries, which are coagulated and transected at the point of origin of the hypogastric artery with a $\mathrm{Li}$ ga-Sure ${ }^{\circledR}$ laparoscopic bipolar coagulator $(5 \mathrm{~mm}$ blunt tip, Medtronic). The ureters are freed from the peritoneal adjacent tissue and from the lateral, dorsal and ventral parametrium. The bladder is dissected in order to expose the bladder pillars, which are coagulated and resected from the posterior bladder wall. The vagina is sectioned $1 \mathrm{~cm}$ below the cervix with a monopolar hook (Karl Storz), and the surgical specimen is extracted vaginally. Bilateral pelvic lymphadenectomy is performed prior to hysterectomy when there is suspicion of lymph node metastasis by imaging or during surgery, by dissecting the lymphatic tissue of the common external iliac vessels and the obturator fossa (Fig. 1), applying the conventional surgical borders. The lymphatic tissue is extracted vaginally and subsequently the vaginal vault is sutured in two planes by continuous far and near suture technique using polyglactin $\left(\right.$ Vicryl $\left.^{\circledR}\right)$ 2-0 suture. The uterus (Figs. 2 and 3) and the tissues are assessed by pathologists of our Institute.

\section{Statistical analysis}

Central tendency and dispersion measures were determined for each one of the variables explored in the study, which were expressed as the mean or median, standard deviation or range or percentage, as appropriate. The statistical parameters were obtained by means of the SPSS V 20.0 program (IBM Corporation).

\section{Results}

During the study period, which was comprised between April 2013 and November 2016, 17 patients were treated with LRH and bilateral pelvic lymphadenectomy. Average age was 42 years (range: 32-61 years),

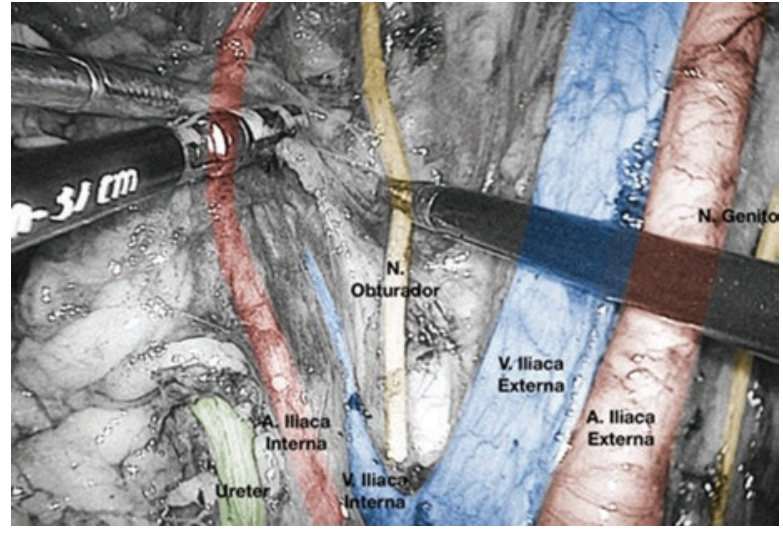

Figure 1. Anatomical structures identified during pelvic lymphadenectomy (right side).

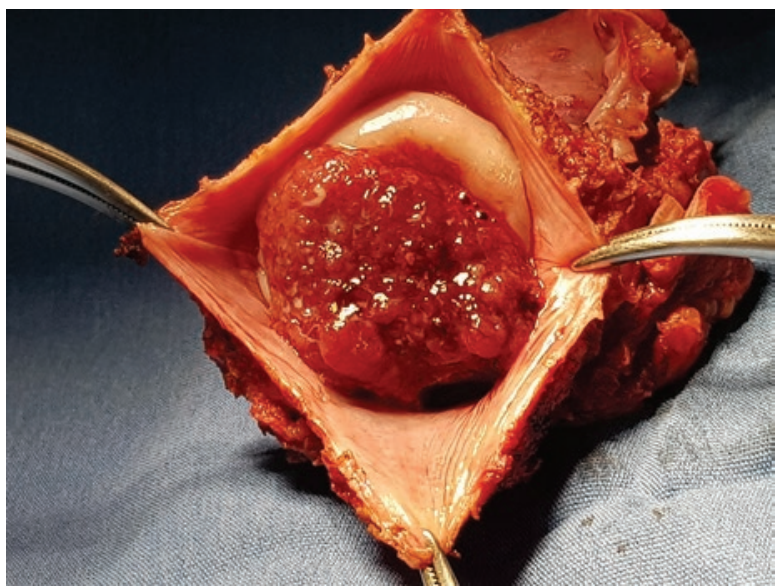

Figure 2. Radical hysterectomy pathology specimen, showing the relationship between the tumor and the unaffected cervix and vaginal margins.

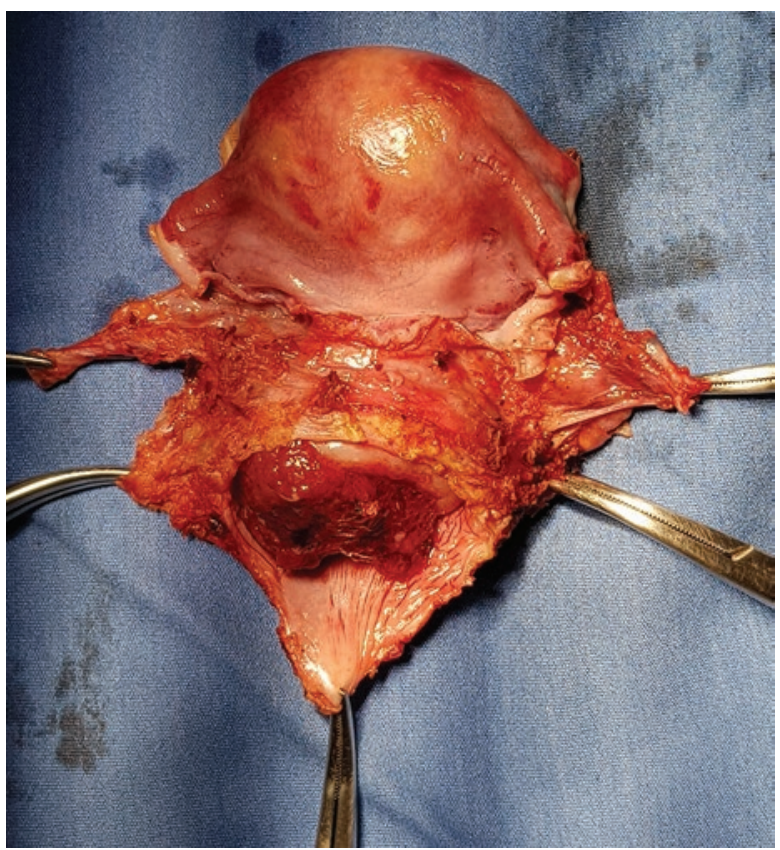

Figure 3. Radical hysterectomy pathology specimen, with lateral parametria and uterine artery being visualized. 
body mass index was 27.7 (range: 19.2-35.7) and all cases were classified as clinical stage 1B1 (Table 1). Thirteen type B and four type C1 (Querleu-Monrrow classification) radical hysterectomies were practiced ${ }^{9}$. Average surgical time was $341 \pm 65$ minutes (mean \pm standard deviation), average blood loss was $107 \mathrm{~mL}$ (range: 20-250) and no patient required blood transfusion. There were no transoperative complications or conversion to conventional approach. Postoperatively, average hospital stay was 2.7 days (range: $2-7$ ); only one case remained for 7 days due to febrile syndrome associated with a urinary tract infection that remitted with antibiotic treatment, and no case required intensive therapy (Table 2). The histopathology report confirmed 10 cases $(58.8 \%)$ of squamous cell carcinoma, $4(23.5 \%)$, of adenocarcinoma and $3(17.6 \%)$, of adenosquamous carcinoma; average tumor size was $2.3 \mathrm{~cm}$ (range: $0.5-4)$, the average cervical invasion degree was $1 / 3,9$ patients (52.9\%) had lymphovascular permeation and $1(5.8 \%)$, positive surgical margin. The average number of lymph nodes obtained on bilateral pelvic lymphadenectomy was 16 ( 8 on the right and 8 on the left) (Table 1). Adjuvant treatment was received by $47 \%$ of patients due to the risk of recurrence; half of them $(23.53 \%)$ received radiotherapy (external beam, 50 Gy to the pelvis) and brachytherapy (24 Gy at high rate) alone because they were at intermediate risk, and the other half $(23.53 \%)$ received adjuvant chemotherapy and radiotherapy (external beam radiotherapy and brachytherapy) because they had high-risk factors for recurrence (two due to positive pelvic lymph nodes and one due to positive surgical border). In contrast, $52.94 \%$ did not receive any adjuvant treatment (Table 3). After a median of 13 months (range: 1-25), no recurrences or deaths were reported; only one patient underwent another operation during brachytherapy when she presented with vaginal vault opening, which was resolved with primary vaginal closure without complications.

The comparison of our findings with the main oncological, safety and morbidity results previously found in the literature is shown in table 4.

\section{Discussion}

The use of the laparoscopic approach in the treatment of cervical cancer offers the benefits of lower blood loss, shorter hospital stay in comparison with laparotomy, small incisions, less postoperative pain, faster recovery, better quality of life during the postoperative period, and better cosmetic results, with the procedure being feasible and safe ${ }^{8,10-13}$.
Table 1. Clinicopathological characteristics $(n=17)$

\begin{tabular}{lc}
\hline Age (years) & Median: $\mathbf{4 0}$ (range: 32-61) \\
\hline Body mass index $\left(\mathrm{kg} / \mathrm{m}^{2}\right)$ & 27.7 (range: $19.2-35.7)$ \\
Clinical stage 1B1 & $17(100 \%)$ \\
Tumor size & $2.3 \pm 0.9$ \\
Histological subtype & \\
Squamous cell & $10(58.8 \%)$ \\
Adenocarcinoma & $4(23.5 \%)$ \\
Adenosquamous & $3(17.6 \%)$ \\
Pathology report & \\
Parametria & \\
Negative & $17(100 \%)$ \\
Surgical margins & \\
Positive & $1(5.8 \%)$ \\
Negative & $16(94.1 \%)$ \\
Stromal infiltration & \\
$1 / 3$ & $9(52.9 \%)$ \\
$2 / 3$ & $4(23.5 \%)$ \\
$3 / 3$ & $4(23.5 \%)$ \\
Lymphovascular permeation & \\
Positive & $9(52.9 \%)$ \\
Negative & \\
\hline Data are reported as means $( \pm$ standard deviation) or $n(\%)$ &
\end{tabular}

Data are reported as means ( \pm standard deviation) or $n(\%)$.

Table 2. Perioperative data $(n=17)$

Average lymph nodes obtained in the lymphadenectomy $\quad 16 \pm 7$

Positive lymph nodes

$0(\%)$

Blood loss ( $\mathrm{mL}$ )

$107( \pm 64)$

Transfusions

0

Surgical time (min)

$341( \pm 65)$

Hospital stay duration

2 days

3 days

4 days

7 days

$12(70.5 \%)$

$1(5.8 \%)$

$3(17.6 \%)$

$1(5.8 \%)$

$0(0 \%)$

Deaths

Data are reported as means ( \pm standard deviation) or $n(\%)$.

Table 3. Follow-up and adjuvant treatment $(n=17)$

\begin{tabular}{lc}
\hline Follow-up (months) & $14( \pm 8)$ \\
Adjuvant treatment & \\
None & $9(52.94 \%)$ \\
RT and BT (due to intermediate risk of recurrence) & $4(23.53 \%)$ \\
CT/RT and BT (due to high risk of recurrence) & $4(23.53 \%)$ \\
Recurrences & $0(0 \%)$ \\
Deaths & $0(0 \%)$ \\
\hline
\end{tabular}

Data are reported as means ( \pm standard deviation) or $n(\%)$.

BT: brachytherapy; CT: chemotherapy; RT: radiotherapy.

LRH offers the benefit of a reduction in blood loss in comparison with open radical hysterectomy, as reported in the studies by Puntambekar et al..$^{14}$ and Kong 


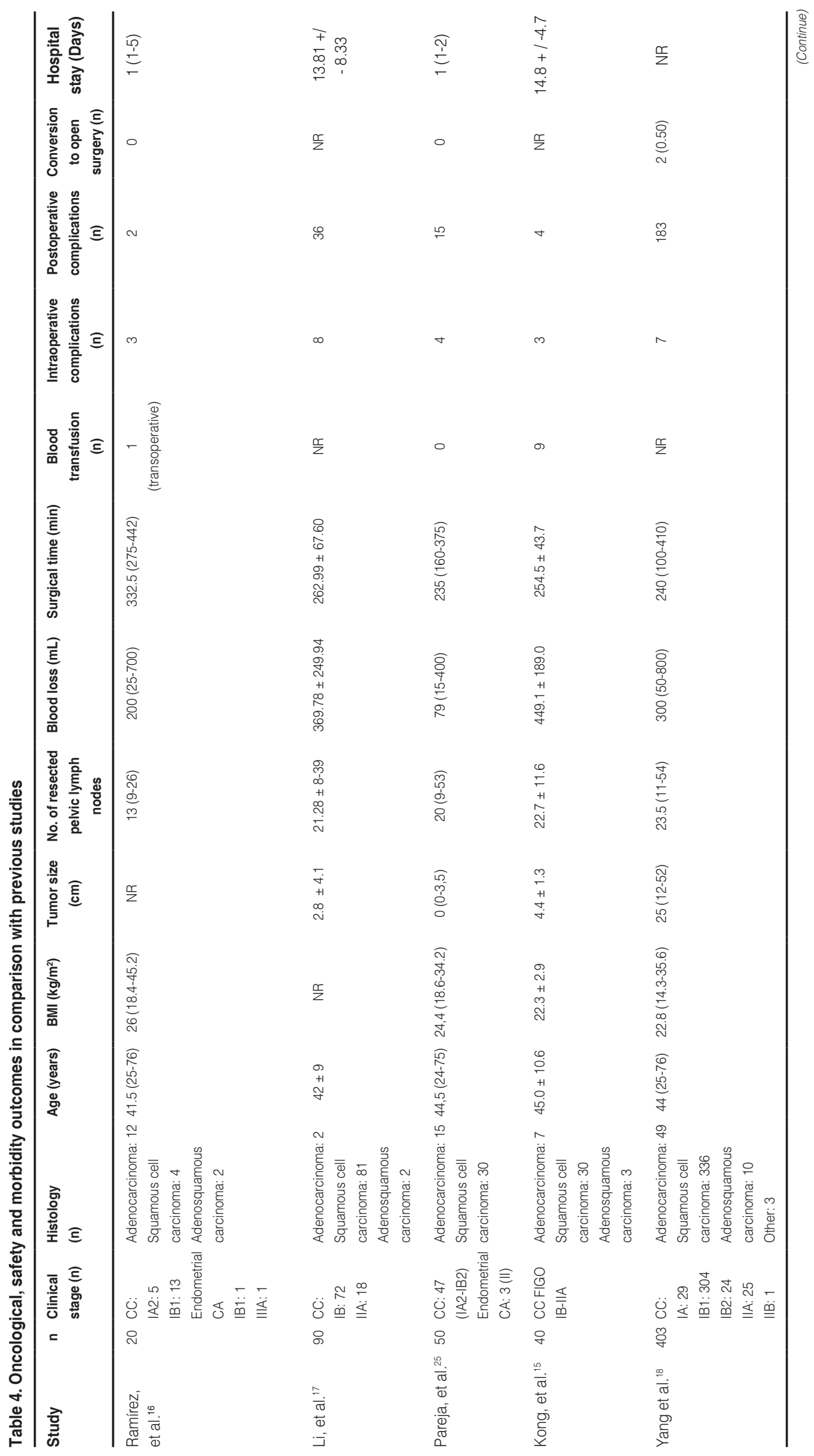




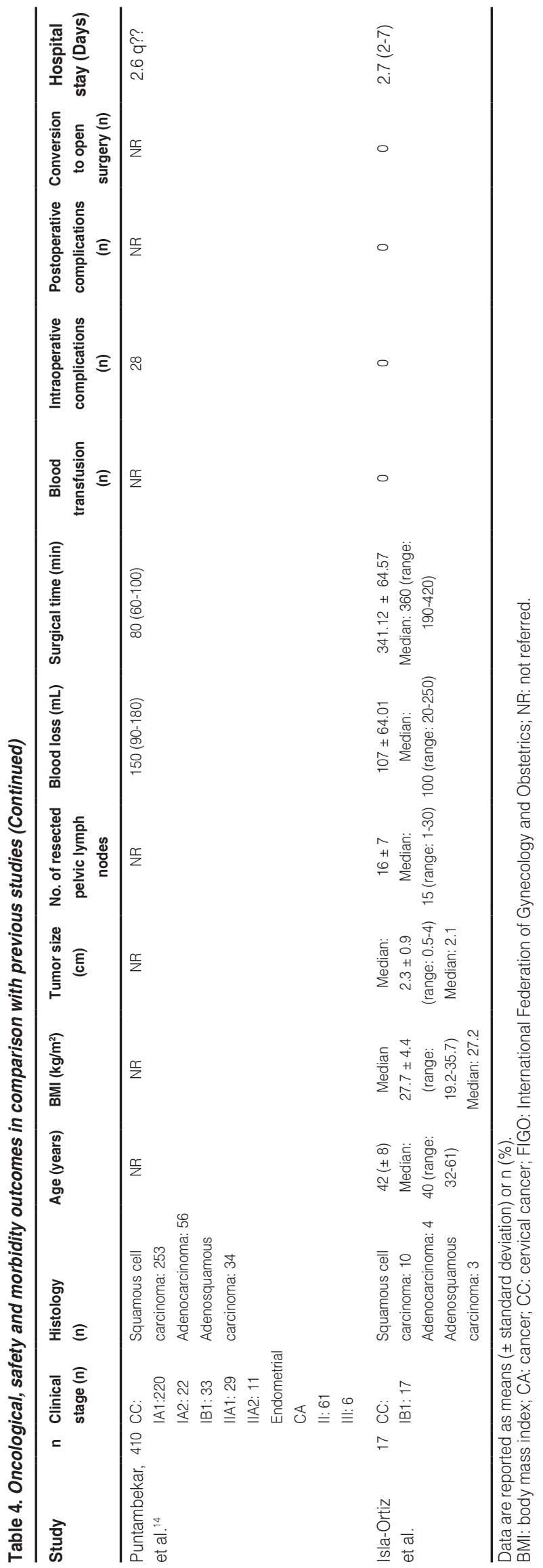

et al. ${ }^{15}$, as well as in the randomized trial by Naik et $\mathrm{al}^{10}{ }^{10}$, where radical hysterectomy with laparoscopic versus abdominal approach was compared, with significant advantages of the laparoscopic approach over the abdominal approach being demonstrated, specifically lower blood loss (400 versus $1000 \mathrm{~mL}$ ), a shorter duration of bladder catheterization (4 versus 21 days), lowe opiate requirements during the first 36 hours after surgery (30 versus $53 \mathrm{mg}$ ) and a shorter hospital stay ( 5 versus 7 days), although the laparoscopic approach took longer (4 versus 2.3 hours).

In our study, blood loss was $107 \mathrm{~mL}$, and average days of hospital stay were 2.7, which is even lower than those reported by Naik et al. ${ }^{10}$ for laparoscopic surgery; however, surgical time exceeded previously reported figures by an average of 1.5 hours.

Regarding surgical times, in the study by Ramírez et al. $^{16}$, the reported surgical time average was 332 minutes, which is similar to the operative time average of 341 minutes in our study; however, the time reported by Puntambekar et al. ${ }^{14}$ was 80 minutes on average, which is the lowest $\mathrm{LRH}$ time recorded. Furthermore, they reported that average hospital stay was one day, which are values that are significantly lower to those reported for historical controls undergoing open radical hysterectomy. The number of lymph nodes resected in our study was 16 , which is a similar number to that reported by Ramírez et al. ${ }^{16}$, with 13 lymph nodes, and by Li et al. ${ }^{17}$, with 21.28.

The limitations of conventional laparoscopy include two-dimensional visualization, an unstable camera platform, and limited degrees of movement using an instrument inside the body, as well as ergonomic difficulty, fine tremor amplification, and difficulty in performing complex surgical procedures in some circumstances, such as presence of dense adhesions in the abdomen.

One of the main complications of radical hysterectomy is postoperative bladder dysfunction. In the study by Ramírez et al. ${ }^{16}$, none of the patients suffered bladder dysfunction. The rates of bladder dysfunction reported in the literature are as high as $20 \%$ after open abdominal radical hysterectomy. In the study by Li et al. ${ }^{17}$, a significant decrease in the urinary retention rate was found in patients undergoing $L R H$ in comparison with open abdominal hysterectomy, and in the study by Yang et al. ${ }^{18}, 37.25 \%$ of patients had bladder dysfunction. Limiting the radicalness of surgery can minimize this morbidity. Other complications reported for LRH include urethral injury, urethral fistulas and vesicovaginal fistula, which are similar lesions to those that occur in open radical hysterectomy. As 
for urethral injury, in the study by Kong et al. ${ }^{15}$ an incidence rate of $1.9-2.3 \%$ has been reported; this elevated rate may be due to the fact that this study included patients with a tumor diameter $\geq 3 \mathrm{~cm}$, since, in most studies, included patients are at FIGO stage IA1 to IB1. Intraoperative complications in a series of 404 patients who underwent LRH occurred in seven patients, and the conversion rate to open surgery was $0.50 \% .^{18}$

Conventional laparoscopy learning curve has been a problem for new surgeons. Wattiez et al. ${ }^{19}$ published a retrospective comparative study on the LRH learning curve of 1647 cases, and concluded that surgical times and main complications significantly decreased after appropriate training. Serna et al. ${ }^{20}$ identified that, on average, $50 \mathrm{LRH}$ procedures have to be practices in order for a surgeon to be able to perform the intervention in an average time of less than 90 minutes; however, after $200 \mathrm{LRHs}$ a plateau is reached, with surgery times of around 83 minutes being established. Furthermore, practice enables the surgeon to increase his/her skills and gradually reduce blood loss, with a loss of $75.4 \mathrm{~mL}$ occurring in the first 200 surgeries and decreasing to $52.6 \mathrm{~mL}$ after 420 laparoscopies. To achieve a rate of laparoconversion of $3 \%$ or less, performing $50 \mathrm{LRHs}$ is necessary, which gradually decreases as more hysterectomies are practiced. The rate of minor complications after having the experience of $200 \mathrm{LRHs}$ is $6 \%$, and this percentage remains stable even after practicing more than 600 surgical interventions.

Perino et al. ${ }^{21}$ compared surgical times between abdominal hysterectomies and $\mathrm{LRH}$, and identified that, for abdominal hysterectomy, surgical time is stabilized at 87 minutes after 15 surgeries, but that with the laparoscopic approach, the first 15 interventions take around 129 minutes, and between the $16^{\text {th }}$ and the $51^{\text {st }}$ the time gets to be decreased down to 93 minutes.

In the study carried out in Finland by Brummer et al. ${ }^{22}$, they noted that as the number of laparoscopic surgeries increases, the rate of major complications is significantly reduced, with almost 7 years being required in order for the learning curve to reach its plateau. More specifically, Mäkinen et al. ${ }^{23}$ refer that 30 interventions are necessary to reduce urethral and bladder injuries.

According to the surgical practice learning curve proposed by Hopper et al. ${ }^{24}$, the acceptable standard should be reached after 50 laparoscopic procedures, with the surgeon being able to control the time and major complications. The highest level of skill and the lowest percentage of laparoconversion are reached at 100 interventions and, after 150 surgeries, total and minor complications should be lower than $10 \%$.

The extent of radical resection that can be achieved with the laparoscopic approach is controversial. Comparative and observational studies have reported that there is no difference in the extent of resection between the laparoscopic and abdominal approaches, but there are randomized studies showing that patients in the laparoscopic group had a decrease in the extent of resected tissue in the vaginal vault (1.3 vs. $2.2 \mathrm{~cm})$, the cardinal ligament $(1.3 \mathrm{vs} .2 .8 \mathrm{~cm})$ and the uterosacral ligament $(1.5 \text { vs. } 4.7 \mathrm{~cm})^{8,10,12}$.

The study by Pareja et al. ${ }^{25}$ suggests that LRHs can be carried out in a similar way in developed countries, such as the USA, and developing countries, such as Colombia, with similar results in terms of blood loss during the intervention, surgical times and hospital length of stay after laparoscopy.

Currently, the Laparoscopic Approach to Cervical Carcinoma $(\mathrm{LACC})^{26}$ clinical trial, an international, multicenter, randomized study that has the purpose to compare disease-free survival in patients who undergo LRH or open radical hysterectomy for cervical cancer at clinical stages IA1 and IB1 with lymphovascular permeation, with adenocarcinoma, squamous cell or adenosquamous carcinoma histological types, is underway. In Mexico, patient recruitment started in July 2015.

\section{Conclusions}

The advantages of the laparoscopic approach include a reduction in surgical time, decreased blood loss and shorter hospital stay. Our results show that the quality of LRH surgical technique in our institution is comparable with that reported in the world literature. These findings support the need to conduct surgical, multicenter and international studies that include developing countries.

\section{Conflicts of interest}

The authors declare not having any conflicts of interest.

\section{References}

1. Arbyn M, Autier P, Ferlay J. Burden of cervical cancer in the 27 member states of the European Union: estimates for 2004. Ann Oncol. 2007; 18:1423-5. 
2. Ferlay J, Soerjomataram I, Dikshit R, Eser S, Mathers C, Rebelo M, et al. Cancer incidence and mortality worldwide: sources, methods and major patterns in GLOBOCAN 2012. Int J Cancer. 2015;136:E359-86.

3. World Health Organization. Comprehensive cervical cancer control: a guide to essential practice. $2^{\text {nd }}$ ed. Geneva: WHO; 2014.

4. Díaz JP, Sonoda Y, Leitao MM, Zivanovic O, Brown CL, Chi DS, et al Oncologic outcome of fertility-sparing radical trachelectomy versus radical hysterectomy for stage IB1 cervical carcinoma. Gynecol Oncol. 2008; 111:255-60.

5. Koh WJ, Greer BE, Abu-Rustum NR, Apte SM, Campos SM, Cho KR, et al. Cervical cancer, Version 2.2015. J Natl Compr Canc Netw. 2015; 13:395-404; quiz 404.

6. Canis M, Mage G, Wattiez A, Pouly JL, Manhes H, Bruhat MA. [Does endoscopic surgery have a role in radical surgery of cancer of the cervix uteri?]. J Gynecol Obstet Biol Reprod (Paris). 1990;19:921.

7. Nezhat CR, Burrell MO, Nezhat FR, Benigno BB, Welander CE. Laparoscopic radical hysterectomy with paraaortic and pelvic node dissection. Am J Obstet Gynecol. 1992;166:864-5.

8. Steed H, Rosen B, Murphy J, Laframboise S, De Petrillo D, Covens A A comparison of laparoscopic-assisted radical vaginal hysterectomy and radical abdominal hysterectomy in the treatment of cervical cancer. Gynecol Oncol. 2004;93:588-93.

9. Querleu D, Morrow CP. Classification of radical hysterectomy. Lancet Oncol. 2008;9:297-303.

10. Naik R, Jackson KS, Lopes A, Cross P, Henry JA. Laparoscopic assisted radical vaginal hysterectomy versus radical abdominal hysterectomy - a randomised phase II trial: perioperative outcomes and surgicopathological measurements. BJOG. 2010;117:746-51.

11. Malur S, Possover M, Michels W, Schneider A. Laparoscopic-assisted vaginal versus abdominal surgery in patients with endometrial cancer - a prospective randomized trial. Gynecol Oncol. 2001;80:239-44.

12. Hertel H, Kohler C, Michels W, Possover M, Tozzi R, Schneider A. Laparoscopic-assisted radical vaginal hysterectomy (LARVH): prospective evaluation of 200 patients with cervical cancer. Gynecol Oncol. 2003; 90:505-11.

13. Morgan DJ, Hunter DC, McCracken G, McClelland HR, Price JH, Dobbs SP. Is laparoscopically assisted radical vaginal hysterectomy for cervical carcinoma safe? A case control study with follow up. BJOG. 2007:114:537-42.

14. Puntambekar SP, Sugoor D, Joshi G, Puntambekar SP, Kumbhare S, Sharma V, et al. Single institutional experience of 410 cases of type B \& type C (Querleu Morrow classification) laparoscopic radical hysterectomy. J Minim Invasive Gynecol. 2015;22(6S):S91-2.
15. Kong TW, Chang SJ, Lee J, Paek J, Ryu HS. Comparison of laparoscopic versus abdominal radical hysterectomy for FIGO stage IB and IIA cervical cancer with tumor diameter of $3 \mathrm{~cm}$ or greater. Int J Gynecol Cancer. 2014;24:280-8.

16. Ramírez PT, Slomovitz BM, Soliman PT, Coleman RL, Levenback C. Total laparoscopic radical hysterectomy and lymphadenectomy: the M.D. Anderson Cancer Center experience. Gynecol Oncol. 2006;102:252-5.

17. Li G, Yan X, Shang H, Wang G, Chen L, Han Y. A comparison of laparoscopic radical hysterectomy and pelvic lymphadenectomy and laparotomy in the treatment of Ib-Ila cervical cancer. Gynecol Oncol. 2007; 105:176-80.

18. Yang L, Cai J, Dong W, Shen Y, Xiong Z, Wang H, et al. Laparoscopic radical hysterectomy and pelvic lymphadenectomy can be routinely used for treatment of early-stage cervical cancer: a single-institute experience with 404 patients. J Minim Invasive Gynecol. 2015;22:199-204.

19. Wattiez A, Soriano D, Cohen SB, Nervo P, Canis M, Botchorishvili R, et al. The learning curve of total laparoscopic hysterectomy: comparative analysis of 1647 cases. J Am Assoc Gynecol Laparosc. 2002;9:339-45.

20. Serna E, Riaño G, Almanza L, De los Ríos J, Castañeda J, Calle G, et al. Histerectomía laparoscópica total, curva de aprendizaje: experiencia de Clínica del Prado, Medellín, Colombia. Rev Chil Obstet Ginecol. 2010;75:367-74.

21. Perino A, Cucinella G, Venezia R, Castelli A, Cittadini E. Total laparoscopic hysterectomy versus total abdominal hysterectomy: an assessment of the learning curve in a prospective randomized study. Hum Reprod. 1999:14:2996-9.

22. Brummer TH, Seppala TT, Harkki PS. National learning curve for laparoscopic hysterectomy and trends in hysterectomy in Finland 2000-2005. Hum Reprod. 2008;23:840-5.

23. Mäkinen J, Johansson J, Tomás $C$, Tomás E, Heinonen PK, Laatikainen T, et al. Morbidity of 10110 hysterectomies by type of approach. Hum Reprod. 2001;16:1473-8.

24. Hopper AN, Jamison MH, Lewis WG. Learning curves in surgical practice. Postgrad Med J. 2007;83:777-9.

25. Pareja R, Nick AM, Schmeler KM, Frumovitz M, Soliman PT, Buitrago CA, et al. Quality of laparoscopic radical hysterectomy in developing countries: a comparison of surgical and oncologic outcomes between a comprehensive cancer center in the United States and a cancer center in Colombia. Gynecol Oncol. 2012;125:326-9.

26. Obermair A, Gebski V, Frumovitz M, Soliman PT, Schmeler KM, Levenback $C$, et al. A phase III randomized clinical trial comparing laparoscopic or robotic radical hysterectomy with abdominal radical hysterectomy in patients with early stage cervical cancer. J Minim Invasive Gynecol. 2008;15:584-8. 